\section{Interleukin-10 and Interleukin-1 receptor antagonists increase during cardiac surgery}

Takae Kawamura MD, PHD, Reiji Wakusawa MD, PHD, Katsuya Inada PHD

Background: It has been reported that inflammatory cytokines such as interleukin-8 and 6 (IL-8. IL-6) increase during cardiac surgery and cause postoperative cardiac dysfunction. Therefore, it is important to investigate changes of suppressive cytokines such as IL-10, interleukin-4 (IL-4) and interleukin-1 receptor antagonist (IL-I ra) duning cardiac surgery.

Method: Serum levels of cytokines and IL-I ra were measured in 10 patients during cardiac surgery with cardiopulmonary bypass. Six blood samples were drawn after inducing anaesthesia. In each sample, serum IL-10. IL-4, IL-8, IL-6 and IL-I ra were measured by enzyme linked immunosorbent assay.

Results: Serum IL-6 and IL-8 concentration $\left(19.1 \pm 8.8 \mathrm{pg} \cdot \mathrm{ml}^{-1}\right.$, and $13.4 \pm 5.2 \mathrm{pg} \cdot \mathrm{ml}^{-1}$. preoperatively) increased to $227.5 \pm 191 \mathrm{pg} \cdot \mathrm{ml}^{-1}$ and $81.0 \pm 56 \mathrm{pg} \cdot \mathrm{ml}^{-1}$ at $60 \mathrm{~min}$ after dedamping the aorta $(P<0.01$, respectively). Serum IL-10 concentration increased at $60 \mathrm{~min}$ after declamping the aorta compared with the preoperative value (from $1.0 \pm 0 \mathrm{pg} \cdot \mathrm{ml}^{-1}$ to $\left.552.0 \pm 158 \mathrm{pg} \cdot \mathrm{ml}^{-1} \mathrm{P}<0.00 \mathrm{I}\right]$ ). Similarty, serum IL-I ra concentration increased from the preoperative value of $1331 \pm 896 \mathrm{pg} \cdot \mathrm{ml}^{-1}$ to $43353 \pm 12812 \mathrm{pg} \cdot \mathrm{ml}^{-1}$ at $60 \mathrm{~min}$ after declamping the aorta $(P<0.001)$. Positive correlations were obtained between IL-10 and IL-8, and between IL-10 and IL-6 $(\gamma=0.7$. $\gamma=0.8, P<0.001$, respectively).

Conclusion: These findings demonstrate that pro-and anti-inflammatory cytokines increase to maintain their balance during cardiac surgery

Objectif : On a rapporté que la concentration des cytokines de linflammation comme les interleukines 6 et 8 (IL-8, IL-6) s'élevaient pendant la chirurgie cardiaque et provoquaient des dérangements cardiaques postopératoires. II est donc aussi important d'examiner les perturbations produites par les cytokines suppressives comme IL10, interleukine-4 (IL-4) et de l'antagoniste du récepteur de l'interleukine-I (IL-I ra) pendant la chirurgie cardiaque.

Méthodes : La concentration sérique des cytokines et de IL-I ra a été mesurée chez dix patients pendant une chirurgie cardiaque sous CEC. Six échantillons de sang ont été prélevés après l'induction de l'anesthésie. Dans chacun des échantillons, on a titré IL-10, IL-4, IL-8, IL-6 et IL-I ra avec l'épreuve de l'immuno-absorption enzymatique.

Résultats : Les concentrations de IL-6 et de IL- 8 (valeurs préopératoires : $19,1 \pm 8,8 \mathrm{pg} \cdot \mathrm{ml}^{-1}$ et $13,4 \pm 5,2$ $\mathrm{pg} \cdot \mathrm{ml}^{-1}$ ) ont augmenté à $227,45 \pm 191 \mathrm{pg} \cdot \mathrm{ml}^{-1}$ et $81,0 \pm 56 \mathrm{pg}^{-1} \mathrm{ml}^{-1} 60 \mathrm{~min}$ après le déclampage de l'aorte (respectivement $P<0,01$ ). La concentration sérique de $\mathrm{IL}-10$ a augmenté 60 min après le déclampage de l'aorte comparativement aux valeurs préopératoires (de $1.0 \pm 0 \mathrm{pg} \cdot \mathrm{ml}^{-1}$ à $552 \pm 158 \mathrm{pg} \cdot \mathrm{ml}^{-1}, P<0.001$ ). De la méme façon, la concentration sérique de IL-Ira a augmenté de la valeur préopératoire de $1331 \pm 896 \mathrm{pg} \cdot \mathrm{ml}^{-1}$ à 4 $3353 \pm 12812 \mathrm{pg} \cdot \mathrm{ml}^{-1} 60 \mathrm{~min}$ après le dédlampage $(P<0,00 \mathrm{I})$. La corrélation était positive entre IL-10 et IL-8 et entre IL-10 et IL-6 (respectivement $\gamma=0,7, \gamma=0,8, P<0,001$ ).

Conclusion : Ces données montrent que les cytokines pro- et anti-inflammatoires augmentent pour maintenir leur équilibre pendant la chirurgie cardiaque.

From the Department of Anaesthesiology, School of Medicine, Iwate Medical University, 19-1, Uchimaru, Morioka, Iwate 020 Japan Address correspondence to: Takae Kawamura MD, Tel.81-196-51-5111; FAX.81-196-23-4112.

Accepted for publication September 20,1996. 


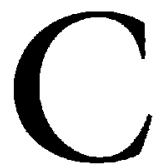

ARDIAC surgery leads to a well recognized pro-inflammatory response. This response has been demonstrated by an increase in plasma pro-inflammatory cytokines. These include TNF- $\alpha$, IL-1, IL- 6 and IL-8. ${ }^{1,2}$

Inflammatory cytokines (IL-1, TNF, IL-6, IL-8 etc), which are produced from monocytes, macrophages or endothelial cells, have been reported to play an important role in the interaction between neutrophils and vascular endothelium. ${ }^{3}$ In a previous study, we found that IL- 8 and IL- 6 increased after declamping of the aorta and that there were positive correlations between IL- 8 and CK-MB, and between IL- 6 and CK-MB. ${ }^{2}$ These results suggested that these cytokines participate in reperfusion injury. It is therefore important to determine whether IL-10, IL-4, and IL-lra, which are potent inhibitors of pro-inflammatory cytokines ${ }^{4-8}$ increase. IL-10 is a recently characterized cytokine 4 that has been implicated in the regulation of lymphoid and myeloid cells ${ }^{5}$ function because of its ability to suppress the synthesis of inflammatory cytokines from $\mathrm{T}$ cells and monocytesmacrophages. ${ }^{6}$ On the other hand, IL-4, defined as B cell stimulating factor, has been found to be a potent down-regulator of human monocyte-macrophage functions such as production of cytokines. ${ }^{7,8}$ In this study, we observed changes of IL-10 and IL-4, which are potent inhibitor of inflammatory cytokines such as IL-8 and IL-6, during cardiac surgery. In addition, we also observed changes of IL-1ra because IL-10 has been reported to up-regulate IL-1ra.

\section{Methods}

With institutional approval and informed consent, we studied 10 patients undergoing elective cardiac surgery. Preanaesthetic medications included 0.2 $\mathrm{mg} \cdot \mathrm{kg}^{-1}$ diazepam, $1 \mathrm{mg} \cdot \mathrm{kg}^{-1}$ hydroxyzine, $1 \mathrm{mg} \cdot \mathrm{kg}^{-1}$ meperdine and $0.01 \mathrm{mg} \cdot \mathrm{kg}^{-1}$ atropine im. Anaesthesia was induced with $30 \mu \mathrm{g} \cdot \mathrm{kg}^{-1}$ fentanyl, and tracheal intubation was facilitated with $0.15 \mathrm{mg} \cdot \mathrm{kg}$ vecuronium. Anaesthesia was maintained using oxygen, and a high-dose of fentanyl (total $100 \mu \mathrm{g} \cdot \mathrm{kg}^{-1}$ ). Ventilation was controlled to maintain $\mathrm{PaCO}_{2}$ at approximately $40 \mathrm{mmHg}$. The perfusion apparatus included a Hollow fibre membrane oxygenator (Termo, Capiox) and nonpulsatile roller-pump (Pemco Inc). A mixture of $20 \%$ mannitol, $7 \%$ sodium bicarbonate, electrolyte solution, and CPD-added preserved blood was primed, and then perfused at a flow rate of $2.4 \mathrm{l} \cdot \mathrm{min}^{-1}$. Haematocrit levels were maintained at $20 \%$ or more throughout CPB. Body temperature was cooled to $<30^{\circ} \mathrm{C}$. All CPB was performed under mild hypothermia $\left(30^{\circ} \mathrm{C}\right)$ with cold blood cardioplegia antegrade/retrograde myocardial preservation. Cardioplegic arrest was induced with cold blood cardioplegia via the antegrade (ascending aortic) route until arrest was achieved. Proximal aorticsaphenous anastomoses were preformed with aortic perfusion and partial occluding clamp. The ECG, EEG, and oesophageal and rectal temperatures were monitored continuously. Arterial blood oxygen saturation was also monitored continuously with a pulse oximeter (Datex, Satlite), and end tidal carbon dioxide concentrations with capnography (Datex, Capnomac). A catheter was placed in the radial artery to measure direct arterial pressure, and from which blood samples were drawn. Six blood samples were drawn after inducing anaesthesia, at the following times: before operation, before starting $\mathrm{CPB}, 60 \mathrm{~min}$ after aortic occlusion, and 60,120 and $180 \mathrm{~min}$ after declamping the aorta. In each sample, serum IL-10, IL-4, IL-8, IL-6 and IL-1 ra concentrations were measured by enzyme linked immunosorbent assay (ELISA) kits (IL10: BioSource International, Camarillo, CA, USA, IL4: Medgenix Diagnostics SA, Belgium, IL-8: R\&D systems, Minneapolis, MN, USA, IL-6: Toray Fujibionics Inc, Tokyo, Japan, IL-lra: Amersham International plc, UK.) The minimum detection limits of these assays for IL-10, IL-4, IL-8, IL-6 and IL- 1 ra were $5,2,3,10$ and $22 \mathrm{pg} \cdot \mathrm{ml}^{-1}$. The coefficents of variation of these assays for IL-10, IL-4, IL-8, IL-6 and IL-l ra were all less than $10 \%$.

For statistical analysis, repeated measures ANOVA was used for serial measurement. Significant difference was defined as $\mathrm{P}<0.05$.

\section{Results}

The patient's age, body weight, ejection fraction, CPB time, and aortic clamp time are shown in Table I. Serum IL-10 concentration $\left(1 \pm 0 \mathrm{pg} \cdot \mathrm{ml}^{-1}\right.$ preoperatively) peaked at $552 \pm 158 \mathrm{pg} \cdot \mathrm{ml}^{-1}$ at $60 \mathrm{~min}$ after

TABLE I Clinical characteristics

\begin{tabular}{lllllll}
\hline Patient & Age & Weight & Diag & CPB & A clamp & EF \\
\hline & y5 & $\mathrm{kg}$ & & $\min$ & $\min$ & $\%$ \\
1 & 68 & 67.5 & $\mathrm{AP}$ & 190 & 128 & 75 \\
2 & 58 & 65 & $\mathrm{AP}$ & 129 & 65 & 60 \\
3 & 72 & 35 & $\mathrm{AR}$ & 98 & 66 & 55 \\
4 & 71 & 61 & $\mathrm{AP}$ & 142 & 70 & 66 \\
5 & 36 & 75 & AA,AR & 257 & 142 & 69 \\
6 & 55 & 52 & MR & 112 & 80 & 69 \\
7 & 16 & 61 & AR,MR & 185 & 150 & 40 \\
8 & 50 & 60 & AP & 139 & 82 & 30 \\
9 & 50 & 60 & AP & 139 & 82 & 30 \\
10 & 68 & 64 & AP & 195 & 114 & 48 \\
Mean & 54 & 62 & & 159 & 101 & 55 \\
SD & 17 & 11.6 & & 47.4 & 32.6 & 15.1 \\
\hline
\end{tabular}

Diag diagnosis; $\mathrm{CPB}$ cardiopulmonary bypass time; $\mathrm{A}^{\circ}$ clamp aortic clamp time; EF ejection fraction; AP angina pectoris; AR aortic regurgitation; $M R$ mitral regurgitation; $A A$ aortic aneurysm 


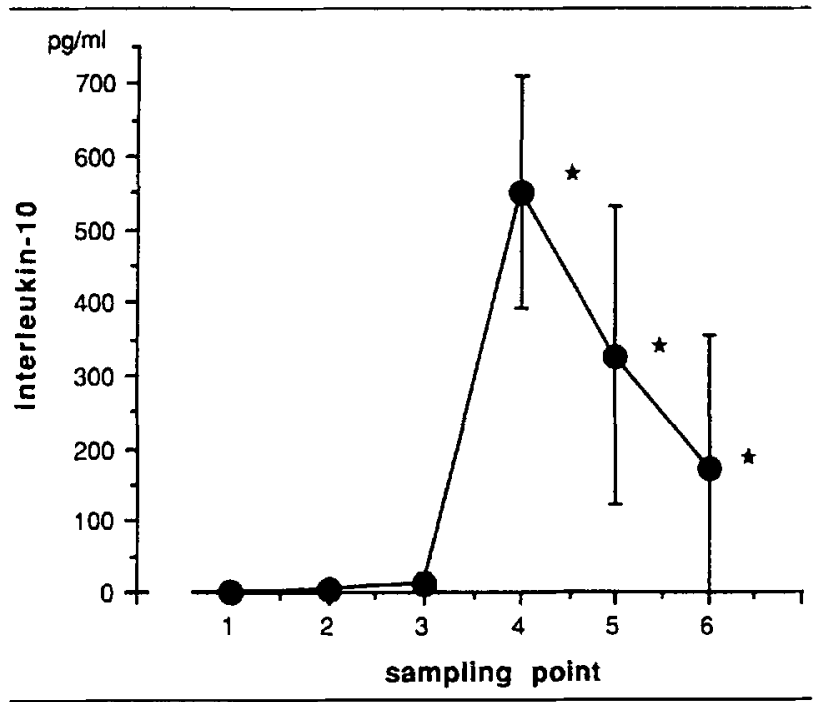

FIGURE 1 Changes of serum interleukin-10 concentration at the following sampling points. (1) before operation , (2) pre-CPB, (3) $60 \mathrm{~min}$ after aortic occlusion, (4) $60 \mathrm{~min}$ after declamping of aorta, (5) $120 \mathrm{~min}$ after declamping of aorta, (6) $180 \mathrm{~min}$ after declamping of aorta.

Mean $\pm \mathrm{SE}, \star P<0.001$ vs $(1),(3)$

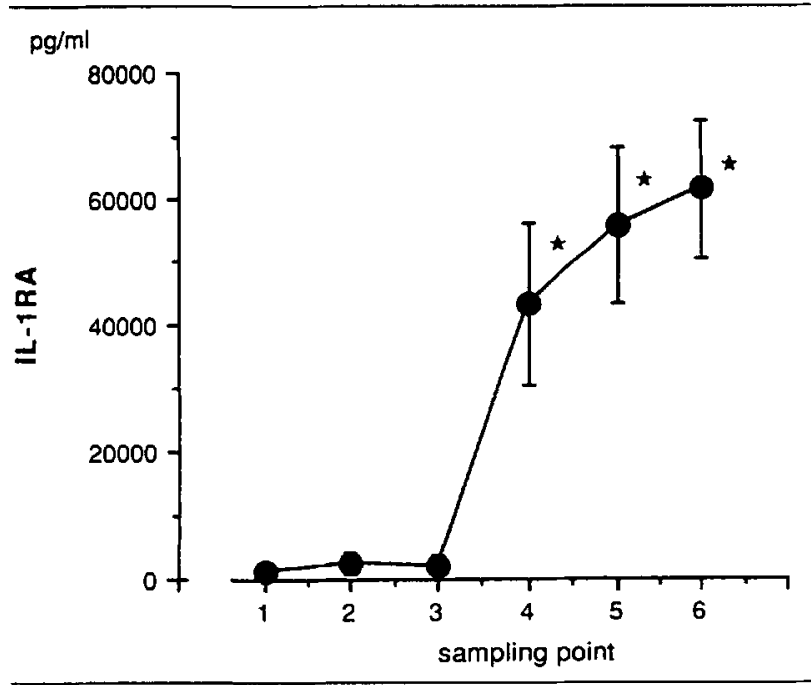

FIGURE 2 Changes of serum interleukin-l receptor antagonist concentration at each time sampling point.

Mean $\pm \mathrm{SE}, \star P<0.001$ ps $(1),(3)$

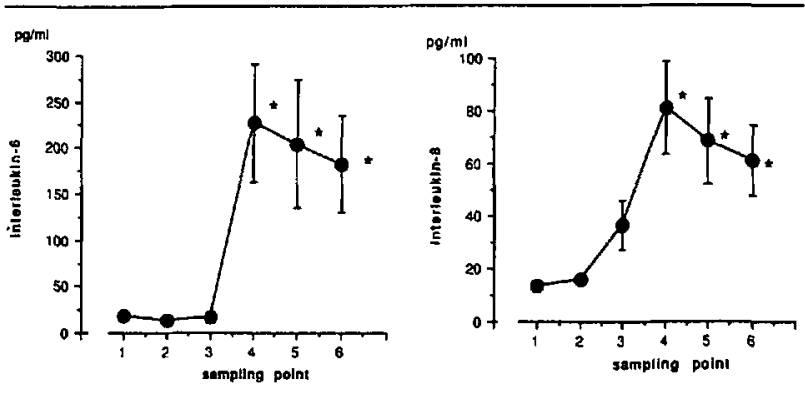

FIGURE 3 Changes of serum interleukin- 6 (left) and interleukin-8 (right) at each sampling point.

Mean \pm SE: $\star P<0.001$ vs $(1),(3)$

declamping of the aorta $(P<0.001)$ and remained elevated at $174 \pm 182 \mathrm{pg} \cdot \mathrm{ml}^{-1} 180 \mathrm{~min}$ after declamping of the aorta $(P<0.001$, Figure 1$)$. The levels of IL-10 at $60,120,180 \mathrm{~min}$ after declamping the aorta were higher than before surgery and at $60 \mathrm{~min}$ after aortic occlusion $(P<0.001$, Figure 1). Serum IL-4 did not change (Table II). Serum IL-l ra concentration increased from $60 \mathrm{~min}$ after declamping the aorta compared with the preoperative and the $60 \mathrm{~min}$.after aortic occlusion levels and peaked $180 \mathrm{~min}$ after declamping the aorta $(P<0.001$, Figure 2$)$.

Serum IL-8 and IL-6 concentrations increased at 60 min after declamping the aorta and remained at a high level until $180 \mathrm{~min}$ after declamping the aorta $(P<0.001$, Table II, Figure 3$)$. Furthermore, the levels of IL-8 and IL-6 at 60, 120, 180 min after declamping of the aorta were higher than that at $60 \mathrm{~min}$ after aortic occlusion $(P<0.001$, Table II, Figure 3). Regression analysis demonstrated a relationship between IL-10 and IL-8 ( $\mathrm{R}=0.7, P<0.000 \mathrm{l})$, and between IL-10 and IL-6 $(R=0.7, P<0.0001)$. IL-10 was also correlated with IL-lra $(=0.42, P<0.001)$.

\section{Discussion}

Cardiac surgery induces systemic inflammatory responses that have been implicated in postoperative organ dysfunction. Recently, the concept of cytokine balance has emerged whereby the balance of pro- and

TABLE II Serum interleukin concentrations at each time.

\begin{tabular}{|c|c|c|c|c|c|c|}
\hline & Sampling & & & & & \\
\hline $\begin{array}{l}\text { IL-8 pg. } \mathrm{ml}^{-1} \\
\text { IL-6 pg. } \mathrm{ml}^{-1} \\
\text { IL-10 pg. } \mathrm{ml}^{-1} \\
\text { IL-4 pg.ml }\end{array}$ & $\begin{array}{l}1 \\
13.4 \pm 5.2 \\
19.1 \pm 8.8 \\
1.0 \pm 0.0 \\
2.4 \pm 2.0\end{array}$ & $\begin{array}{l}2 \\
16 \pm 4.4 \\
13.2 \pm 10.2 \\
1.9 \pm 1.8 \\
2.7 \pm 3.0\end{array}$ & $\begin{array}{l}3 \\
36.2 \pm 29.6 \\
16.9 \pm 10.7 \\
11.3 \pm 14.5 \\
2.4 \pm 3.9\end{array}$ & $\begin{array}{l}4 \\
81.0 \pm 56.0^{*} \\
227.5 \pm 191.0^{\star} \\
552.0 \pm 158.9^{\star} \\
6.1 \pm 4.7\end{array}$ & $\begin{array}{l}5 \\
68.6 \pm 51.0^{\star} \\
204.3 \pm 209.6^{\star} \\
327.3 \pm 204.9^{*} \\
18.9 \pm 41.8\end{array}$ & $\begin{array}{l}6 \\
61.3 \pm 42.8^{*} \\
182.8 \pm 160.8^{*} \\
174.2 \pm 182.7^{*} \\
7.3 \pm 7.8\end{array}$ \\
\hline
\end{tabular}

Sampling times: 1) before operation, 2) pre-CPB, 3) $60 \mathrm{~min}$ after aortic clampling, 4) $60 \mathrm{~min}$ after declamping aorta, 5) $120 \mathrm{~min}$ after declamping aorta, 6) 180 min after declamping aorta.

Mean \pm SD. ${ }^{*} P<0.001$ vs 1 ) and 3 ). 
anti-inflammatory cytokines determine clinical outcome in certain disease states including cardiac surgery. Our previous study showed that IL- 6 and IL8 increased markedly in patients who underwent cardiac surgery with cardiopulmonary bypass. In the present study, changes in anti-inflammatory cytokines were followed in relation to those in pro-inflammatory cytokines. IL-10, IL- 6 and IL-8 changed almost similarly. Peak levels appeared $60 \mathrm{~min}$ after declamping the aorta, and were followed by a gradual decrease. However, high levels were maintained up to 180 min after declamping. IL-10 correlated with IL- 6 and IL-8, suggesting that the increase in IL-10 may be partial compensation for the increased concentration of pro-inflammatory cytokines. IL-lra increased markedly from 60 min after declamping the aorta. Although peak levels of IL-6, IL- 8 and IL-10 appeared at $60 \mathrm{~min}$ after declamping, and were followed by a gradual decrease, IL-l ra increased linearly, and peak levels appeared $180 \mathrm{~min}$ after declamping the aorta. IL-10 is a potent inhibitor of pro-inflammatory cytokines, suggesting that it may also have an important regulatory role in limiting the duration and extent of the acute inflammatory response. ${ }^{9}$ Furthermore, it has been reported that IL-10 up-regulates IL-1 ra and the ability of IL-10 to up-regulate IL-lra production in PMN may reflect one of the mechanisms underlying the immunosuppressive actions of IL-10. ${ }^{5}$ The present study showed that peak levels of IL-10 appeared $60 \mathrm{~min}$ after declamping the aorta, followed by increases in IL-l ra, while the peak production of IL-6 and IL-8 was found 60 min after declamping, and was followed by a decrease. These results indicate that the increased production of IL-10 may have suppressed the production of pro-inflammatory cytokines. It is suggested that IL-10 may exert its anti-inflammatory action by affecting the balance of pro- and anti-inflammatory cytokines. Serum IL-lra increased considerably which suggests excessive local production of IL-1. IL-1, a monokine produced primarily by macrophages, is known to be involved in the host response to injury and infection. ${ }^{11}$ Although inflammatory processes are defence mechanisms, IL-1 may cause tissue damage, including stimulation of TNF- $\alpha$, IL- 8 and IL- 6 , and may contribute to chronic inflammation in unregulated conditions. The action of IL-1 can be controlled in several ways, such as by regulation of its synthesis, ${ }^{12}$ by the release of soluble IL-1 receptors, ${ }^{13}$ or by the production of IL-lra, an antagonistic inhibitor that blocks IL-1 binding to its receptor, ${ }^{14}$ thereby effectively preventing the biological actions of IL-1. ${ }^{15} \mathrm{IL}-\mathrm{lra}$ is a 23 -to $25-\mathrm{KD}$ glycosylated protein, originally purified from supernatants of human monocytes cultured on immune complexcoated surfaces, ${ }^{14}$ or from the urine of parients with monocytic leukaemia, which has been recently cloned. ${ }^{16}$ The IL-lra specifically blocks IL-I $B$ and IL-1B at its receptor level. ${ }^{17}$ The excessive production of IL-6 and IL-8 may be inhibited by suppression of this excessive local production of IL-1. It may be reasonable to retain a physiological state that suppressive cytokines such as IL-1ra and IL-10 increase according to the increased production of IL-8 and IL-6 during cardiac surgery.

These findings suggest that inflammatory cytokines and their suppressive cytokines increase but maintain their balance during cardiac surgery. The inflammatory response to cardiac surgery is thought to be produced by exposing patients to pro-inflammatory trigger factors. These include exposure of blood to the foreign surface of the cardiopulmonary bypass apparatus, myocardial reperfusion after declamping the aorta, reduction in pulmonary blood flow during aortic cross-clamping, and the surgical stress response. In the present study, The production of cytokines did not increase $60 \mathrm{~min}$ after clamping the aorta, but increased considerably $60 \mathrm{~min}$ after declamping. In addition, in a previous study we showed that these changes correlated with the duration of aortic clamping and cardiopulmonary bypass time. These results suggest that the production of cytokines was related to reperfusion injury in the lungs and myocardium following ischaemia and to invasion due to long lasting cardiopulmonary bypass. In summary, our study extends the results of other investigations ${ }^{18-20}$ regarding the balance of pro-and anti-inflammatory cytokines. If the balance breaks, the consequences may infclude myocardial damage and organ failure. Thus, it is necessary to determine the critical level for the ratio of inflammatory and suppressive cytokines. Then, IL10 and IL-1ra may be useful as a therapeutic agent for the treatment of myocardial injury.

\section{References}

1 Butler J, Chong GL, Baigrie RJ, Pillai R, Westaby S, Rocker GM. Cytokine responses to cardiopulmonary bypass with membrane and bubble oxygenation. Ann Thorac Surg 1992; 53: 833-8.

2 Kawamura $T$, Wakusawa $R$, Okada $K$, Inada $K$. Elevation of cytokines during open heart surgery with cardiopulmonary bypass: participation of interleukin 8 and 6 in reperfusion injury. Can J Anaesth 1993;40: 1016-21.

3 Paccaud J-P, Shifferli JA, Baggiolini $M$. NAP-1/IL-8 induces up-regulation of $\mathrm{CRI}$ receptors in human 
neutrophil leukocytes. Biochem Biophys Res Comm 1990; 166: 187-92.

4 Fiorentino DF, Bond MW, Mosmann TR. Two types of mouse $\mathrm{T}$ helper cell. IV Th2 clones secrete a factor that inhibits cytokine production by Thl clones. J Exp Med 1989; 170: 2081-95.

5 Moore KW, O'Garra A, de Waal Malefyt $R$, Vieira $P$, Mosmann TR. Interleukin- 10. Annu Rev Immunol 1993; 11: 165-90.

6 Fiorentino DF, Zlotnik A, Mosmann TR, Howard M, $O^{\prime}$ Garra $A$. IL-10 inhibits cytokine production by activated macrophages. J Immunol 1991; 147: 3815-22.

7 Yanagawa $H$, Sone S, Sugibara $K$, Tanaka $K$, Ogura $T$. Interleukin 4 down-regulates interleukin- 6 production by human alveolar macrophages at protein and mRNA levels. Microbiol Immunol 1991; 35: 879-93.

8 Sone S, Yanagawa $H$, Nishioka $\Upsilon$, et al. Interleukin-4 as potent down-regulator for human alveolar macrophages capable of producing tumour necrosis factor- and interleukin-1. Eur Respir J 1992; 5: 174-81.

9 Cassatella MA, Meda L, Bonora S, Ceska M, Constantin G. Interleukin 10 (IL-10) inhibits the release of proinflammatory cytokines from human polymorphonuclear leukocytes. Evidence for an autocrine role of tumor necrosis factor and IL-1 in mediating the production of IL-8 triggered by lipopolysaccharide. J Exp Med 1993; 178: 2207-11.

10 Cassatella MA, Meda L, Gasperini S, Calzetti F, Bonora $S$. Interleukin 10 (IL-10) up-regulates IL-1 receptor antagonist production from lipopolysaccharide-stimulated human polymorphnuclear leukocytes by delaying mRNA degradation. J Exp Med 1994; 179: 1695-9.

11 Dinarello $C A$. Biology of Interleukin 1. FASEB J 1988; 2: 108-15.

12 Kern JA, Lamb RJ, Reed JC, Daniele RP, Nowell PC. Dexamethasone inhibition of interleukin 1 beta production by human monocytes. Post-transcriptional mechanisms. J Clinical Invest 1988; $81: 237-44$.

13 Colotta $F, \operatorname{Re} F$, Muzio $M$, et al. Interleukin-I type II receptor: a decoy target for $\mathrm{IL}-1$ that is regulated by IL-4. Science 1993; 261: 472-5.

14 Arend WP, Joslin FG, Massoni RJ. Effects of immune complexes on production by human monocytes of interleukin 1 or an interleukin 1 inhibitor. J Immunol 1985; 134: 3868-75.

15 Dinarello $C A$, Wolff $S M$. The role of Interleukin -1 in disease. N Engl J Med 1993; 328: 106-13.

16 Eisenberg SP, Evans RJ, Arend WP, et al. Primary structure and functional expression from complementary DNA of a human interleukin 1 receptor antagonist. Nature 1990; 343: 341-6.

17 Seckinger $P$, Lowentbal JW, Williamson K, Dayer J-M, MacDonald HR. A urine inhibitor of interleukin 1 activity that blocks ligand binding. J Immunol 1987; 139: 1546-9.

18 McBride WT, Armstrong MA, Crockard AD, McMurray $T$, Rea JM. Cytokine balance and immunosuppressive changes at cardiac surgery : contrasting response between patients and isolated CPB cercuits. $\mathrm{Br} J$ Anaesth 1995; 75: 724-33.

19 Girardin E, Roux-Lombard P, Grau GE, et al. Imbalance between tumour necrosis factor-alpha and soluble TNF receptor concentrations in severe meningococcaemia. Immunology 1992; 76: 20-3.

20 Miller LC, Lynch EA, Isa S, Logan JW, Dinarello CA, Steere $A C$. Balance of synovial fluid IL-1 and IL-1 receptor antagonist and recovery from Lyme arthritis. Lancet 1993; 341: 146-8. 